\title{
Heat Tolerance in Sugarcane: Optimum Temperature and Phenological Stage to Determination of Thermotolerance as Selection Criteria
}

\author{
Sergio Castro-Nava ${ }^{1}$, Rafael Delgado-Martínez ${ }^{1} \&$ Jose Manuel García-Girón ${ }^{1}$ \\ ${ }^{1}$ Facultad de Ingeniería y Ciencias, Universidad Autónoma de Tamaulipas. Cd. Victoria, Tamaulipas, México \\ Correspondence: Sergio Castro-Nava, Facultad de Ingeniería y Ciencias, Universidad Autónoma de Tamaulipas. \\ Cd. Victoria, Tamaulipas, México. E-mail: scastro@docentes.uat.edu.mx
}

Received: March 18, 2020

doi:10.5539/jas.v12n8p135

\author{
Accepted: May 9, $2020 \quad$ Online Published: July 15, 2020 \\ URL: https://doi.org/10.5539/jas.v12n8p135
}

\begin{abstract}
Heat stress is the major abiotic stressor in agriculture which reduces crop productivity and yield. Six sugarcane (Sacharum officinarum L.) genotypes were studied to investigate the impact of three temperature levels at four phenological stages on tissue electrolyte production and the feasibility of using the cell thermostability method (CTM) for the identification and selection of heat tolerant sugarcane genotypes. The cell membrane thermostability was quantified by measuring relative cell injury percentage with a modification in the temperature treatment on four phenological stages in a field experiment. Our results suggest that heat tolerance based on cell membrane thermostability can be improved using the existing genetic variability available within the commercial or experimental sugarcane germplasm. We conclude that the cell membrane thermostability test can be a useful screening procedure for selecting sugarcane genotypes that tolerate high temperature stress. The test can be used in conjunction with a temperature trait of $60{ }^{\circ} \mathrm{C}$ during the maturity stage. This procedure predicts the ability of sugarcane genotypes to maintain yield and juice quality under stressful field conditions.
\end{abstract}

Keywords: heat stress, high temperature, relative cell injury, Sacharum officinarum L., sugarcane, thermostability

\section{Introduction}

In recent years, one of the important challenges facing crop physiologists is understanding and overcoming the major abiotic stresses in agriculture (Wahid et al., 2007). One of these stressors particularly predominant in the world is heat stress (Trivedi, 2015), which decreases plant growth and development and also crop productivity and yield (Wahid et al., 2007; Gomathi et al., 2014).

Ambient temperatures are rising at a considerable rate as part of the current global climate change; additionally, climatological extremes such as heat waves are likely to occur more frequently (IPCC, 2013). The intensity, duration, and rate of temperature change together determine the impact of high temperature on plant development and physiology (Wahid et al., 2007).

Sugarcane requires optimum temperature $\left(32-33{ }^{\circ} \mathrm{C}\right)$ for growth, productivity and yield expression, and it is known to tolerate temperatures approaching $40{ }^{\circ} \mathrm{C}$, while high temperatures around $45{ }^{\circ} \mathrm{C}$ are detrimental to sugarcane growth (Wahid et al., 2007). On the non-irrigated zones where the rain is the only source of water, sporadic days with heat extremes above $40{ }^{\circ} \mathrm{C}$ can occur at any development stage during the growing season (Chen et al., 2010).

Global increases in the ambient temperature is an agricultural problem in the world (Wahid, 2007). Transitory or constantly high temperatures cause an array of morpho-anatomical, physiological and biochemical changes in plants, which affect plant growth and development and may lead to a drastic reduction in economic yield (Wahid et al., 2007), as a function of many processes throughout the plant cycle (Masuka et al., 2012). The adverse effects of heat stress can be minimized by developing genetically improved plants using the thermotolerance as a selection strategy.

Heat stress greatly changes the physiological and biochemical phenomena of sugarcane leading to growth and yield suppression (Wahid et al., 2007). Recent research indicates that sugarcane grown under high temperature exhibited smaller internodes and early drying of leaves with increased tillering with reduced biomass (Gomathi et al., 2014). Furthermore, in spite of variation in susceptibility of different development stages to heat stress, 
almost all stages of plant life are affected by heat stress. The developmental stages at which the crop plants are exposed to the stress, may determine the severity of possible damages experienced by the crop (Trivedi, 2015). During heat stress modifications in different plant processes take place in such a way to minimize the effect and develop tolerance to sustain stressful environment (Trivedi, 2015).

Physiological and biochemical screening techniques as a complement to empirical breeding methods could increase selection efficiency (Fischer, 1985). The genes securing heat tolerance may be lost in the breeding programs which rely mainly on only empirical selection (Reynolds et al., 1994).

Heat stress causes loss of integrity and functions of biological membranes due to alteration in the tertiary and quaternary structures of membranes proteins (Trivedi, 2015). Such alterations enhance the permeability of membranes and cause increased leakage of solutes, as an indication of decreased cell membrane thermostability (CMT). The CMT was developed by Sullivan (1972) to measure heat tolerance and determines the thermostability of the cell membrane through the measurement of the amount of electrolytes lost from the foliar tissue after exposure to a heat treatment $\left(>40^{\circ} \mathrm{C}\right)$. Electrolyte leakage tests have been widely used to assess the level of plant tolerance to various stresses in different plant species such as Glycine max L. (Martineau et al., 1979); Solanum tuberosum L. and Lycopersicon esculentum Mill. (Chen et al., 1982); Triticum aestivum L. (Saadalla et al., 1990a; 1990b; Fokar et al., 1998; Blum et al., 2001); Vigna unguiculata L.(Ismail \& Hall, 1999; Thiaw \& Hall, 2004); Gossypium hirsutum L. (Rahman et al., 2004); Sorghum bicolor L. Moench (Sullivan \& Ross, 1979); Oryza sativa L. (Tripathy et al., 2000); Zea mays L. and Phaseolus vulgaris L. (Castro-Nava et al., 2012; Castro, 2013; Castro-Nava et al., 2014); and Sacharum officinarum L. (Wahid \& Close, 2007; Sudhakar et al., 2010; Gomathi et al., 2013). The technique is very simple, rapid, require inexpensive equipment, and can be used on plant material from a variety of crops and it is suitable for the analysis of large numbers of genotypes at the same time.

However, a disadvantage in the method is that the temperatures used vary across crops, ranging from 32 to $52{ }^{\circ} \mathrm{C}$, along with differences in tissue exposure time (Sullivan, 1972; Martineau et al., 1979; Blum \& Ebercon, 1981; Saadalla et al., 1990a; Saadalla et al., 1990b; Ibrahim \& Quick, 2001; Rahman et al., 2004). To identify tolerant genotypes, the plant tissue should be exposed to a temperature where tolerance is indeed expressed; that is, it is necessary to define a temperature where high electrolyte values are induced. In addition, it is necessary to consider the phenological stage in which the methodology is applied to obtain the maximum response (Barnabás et al., 2008). The objective of the study was to investigate three temperature levels for tissue exposure using the thermostability method for six sugarcane cultivars, and determine which of these produced a greater quantity of electrolytes and the establish which is the best phenological stage to identify tolerant genotypes in a selection process.

\section{Materials and Methods}

\subsection{Site, Genotypes and Weather}

The experiment was carried out at the Facultad de Agronomía, Universidad Autónoma de Tamaulipas, Victoria, Tamaulipas, México. The experimental material were six commercial sugarcane genotypes (Mex 68-P23, CP 72-2086, Mex 68-1345, Mex 79-431, RD 75-11 and Mex 95-60). These genotypes were included because they are widely grown in dryland conditions in Mexico, have contrasting agronomic characteristics, and were expected to show different responses to CMT. The experimental material was evaluated for CMT under rainfed conditions. The field experiment was carried out during 2016 and 2017, and was planted on October 15, 2016.

\subsection{Agronomic Management, Treatments and Data Collection}

The general production practices recommended for sugarcane for the growing region were adopted. The experimental area was fertilized at a rate of 103-41-46 NPK per hectare as indicated by Castro et al. (2015). Weed and insect control applications were made when required. CMT was measured following the method proposed by Sullivan (1972) with a modification in the temperature treatment. The temperatures of 40,50 and $60{ }^{\circ} \mathrm{C}$ were used, with a duration of 60 minutes. Treatment temperature was used as suggested Castro (2013) to determine the treatment conditions producing greatest sensitivity in detecting genetic differences. As leaves of different ages might show differential responses, CMT was measured on the second youngest fully expanded leaf at four phenological stages: leaf development, tillering, grand growth and maturity (Bonnett, 2014). Samples collected at each phenological stage from each plot consisted of a paired set (control and heat treated) of 10 leaf discs $(10 \mathrm{~mm}$ diameter) cut from ten randomly selected plants within a central row. Excised samples were immediately placed in glass vials containing $10 \mathrm{ml}$ deionized water to prevent desiccation of leaf tissue and were brought to the laboratory as quickly as possible. In the laboratory, leaf tissue was washed thoroughly with two changes of deionized water to remove electrolytes adhering to leaf tissue, as well as electrolytes released into the 
water. After rinsing, vials were drained and $10 \mathrm{ml}$ deionized water was added to each vial and capped to avoid desiccation and evaporation during heat treatment. Heat treatment vials were covered with aluminum foil. One set of vials was treated in a controlled temperature water bath (Boekel Grant BB-1400) maintained at each temperature treatment for $60 \mathrm{~min}$. The controlled test vials were kept at $28{ }^{\circ} \mathrm{C}$ for the same period. After heat treatment, $10 \mathrm{ml}$ deionized water was added to each vial and held at $10{ }^{\circ} \mathrm{C}$ for $24 \mathrm{~h}$ to allow diffusion of electrolytes. Vials were brought to $28{ }^{\circ} \mathrm{C}$ and shaken to mix the contents. Electrical conductivity (EC) was measured with an EC meter (Digital Conductivity Meter, VWR model CRB-10M). Vials were autoclaved (Felisa, Model FE 399) for $10 \mathrm{~min}$. at $0.10 \mathrm{MPa}$ pressure and $120{ }^{\circ} \mathrm{C}$ to completely kill tissues and release all the electrolytes. Vials were then brought to $28{ }^{\circ} \mathrm{C}$ and the final EC was measured with the same instrument. Percentage relative cell injury (RCI\%), as indicator of CMT, was calculated with the following formula (Sullivan, 1972):

$$
\operatorname{RCI}(\%)=1-\left\{\left[1-\left(\mathrm{T}_{1} / \mathrm{T}_{2}\right)\right] /\left[1-\left(\mathrm{C}_{1} / \mathrm{C}_{2}\right)\right]\right\} \times 100
$$

where, $\mathrm{T}$ and $\mathrm{C}$ refer to $\mathrm{EC}$ values of heat treated and controlled vials, and subscripts 1 and 2 denote initial and final $\mathrm{EC}$ readings, respectively.

\subsection{Statistical Analysis}

The design was a randomized complete block with five replications. The plants were grown in one row of $5 \mathrm{~m}$ length with inter row spacing of $1.30 \mathrm{~m}$. The plot size in each replication was of three rows and 50 plants each one. To assess treatment effects, genotypes, temperature treatment, and phenological stage were considered as fixed effects, and replicate block was considered a random effect. Combined analysis of variance were made using the GLM procedure (SAS, 2010) for RCI to determine variation among the six genotypes. Effects associated with genotype, temperature treatment, phenological stage and their interactions were identified. Mean comparison was performed on the factors using Tukey's Studentized Range Test at the $\mathrm{P}=0.05$ levels. Association among temperature treatment and RCI\% were examined by simple correlation analysis.

\section{Results and Discussion}

Under field conditions, the evaluation of heat tolerance is probably the most relevant approach in a sugarcane breeding program to identify germplasm tolerance. However, meeting this goal under field conditions is extremely difficult because specific higher temperatures do not always occur at specific developmental stages or with right intensity or duration. To overcome this inherent difficulty, we evaluated a modificated CMT method at four phenological stages in six sugarcane genotypes under rainfed conditions, as a selection criterion in a breeding program.

\subsection{Analysis of Variance}

Analysis of variance carried out on relativity cell injury (RCI\%) assessed under three temperature treatments and four phenological stages (Table 1$)$, revealed highly significant effects $(\mathrm{P} \leq 0.01)$ for genotypes, temperature treatment, and phenological stages. Furthermore, genotype by phenological stage and temperature treatment by phenological stage interactions were highly significant $(\mathrm{P} \leq 0.01)$ for $\mathrm{RCI} \%$. Differences between genotypes were observed in previous studies in sugarcane (Sudhakar et al., 2010); wheat (Ibrahim et al., 2001; Yildirim et al., 2009; Saadalla et al., 1990a; Blum et al., 2001; Blum \& Ebercon, 1981; Fokar et al., 1998); cotton (Rahman et al., 2004) and soybean (Martineau et al., 1979). However, reports in relation to the use of CMT in sugarcane using different temperatures and different phenological stages are very rare scanty. 
Table 1. Analysis of variance for CMT as measured by RCI (\%) of six sugarcane genotypes in an experiment conducted in the field under rainfed conditions

\begin{tabular}{llll}
\hline Source of Variation & df & Mean Squares & Probability \\
\hline Replication & 4 & 214,887 & $0.209 \mathrm{~ns}$ \\
Genotypes $(\mathrm{G})$ & 5 & 505,874 & $0.005 * *$ \\
Temperature $(\mathrm{T})$ & 2 & 86588,199 & $0.000 * * *$ \\
Phenological stage $(\mathrm{PhS})$ & 3 & 1775,509 & $0.000 * * *$ \\
$\mathrm{G} \times \mathrm{T}$ & 10 & 132,267 & $0.525 \mathrm{~ns}$ \\
$\mathrm{G} \times \mathrm{PhS}$ & 15 & 365,597 & $0.002 * *$ \\
$\mathrm{~T} \times \mathrm{PhS}$ & 6 & 3787,103 & $0.000 * * *$ \\
$\mathrm{G} \times \mathrm{T} \times \mathrm{PhS}$ & 30 & 350,890 & $0.000 * * *$ \\
Residuals & 284 & 145,406 & \\
$\mathrm{CV}(\%)$ & 27.5 & & \\
\hline
\end{tabular}

Note. ns: Non-significant at $\mathrm{P}>0.05 ; * *$ : Significant at $\mathrm{P} \leq 0.01 ; * * *$ : Significant at $\mathrm{P} \leq 0.001$.

\subsection{Effect of Genotypes}

$\mathrm{RCI} \%$ is an indicator of cellular or tissue heat tolerance; low RCI\% reflects high CMT, and high $\mathrm{RCI} \%$ reflects low CMT (Rahman et al., 2004). Genotypes differed significantly $(\mathrm{P}<0.01)$ among themselves for the expression of RCI\% in the field (Figure 1). Among genotypes, RCI\% ranged between 42 and $50 \%$, and averaged $47 \%$, considering temperature treatments and phenological stages. These RCI\% values indicate a wide difference in heat tolerance among the genotypes, as assessed by the membrane thermostability. Genotype Mex 68 P-23 possessed the lowest RCI\% and Mex 68-1345 the highest. Similar values of RCI\% were observed by Sudhakar et al. (2010) in sugarcane under moisture stress.

\subsection{Effect of Temperature}

Sugarcane genotypes responded differently for RCI\% across temperature treatments. Regardless of the genotype and the phenological stage, the impact of temperature treatment was significant, strongly related because as the temperature increased from 40 to $60{ }^{\circ} \mathrm{C}$, the $\mathrm{RCI} \%$ increased from 18 to $73 \%$ (Figure 2). The increase in the $\mathrm{RCI} \%$ when increasing the temperature from 40 to 50 and $60^{\circ} \mathrm{C}$ was $170 \%$ and $283 \%$, respectively. The increase in the $\mathrm{RCI} \%$ as a result of the increase in temperature during the procedure represented $3.2 \%$ per each ${ }^{\circ} \mathrm{C}$, when increasing from 40 to $50{ }^{\circ} \mathrm{C}$, and $2.67{ }^{\circ} \mathrm{C}$ per each ${ }^{\circ} \mathrm{C}$ when the temperature increased from 40 at $60{ }^{\circ} \mathrm{C}$. On the other hand, when the temperature increased from 50 to $60{ }^{\circ} \mathrm{C}$, the rate of increase was $2.13{ }^{\circ} \mathrm{C}$ for each ${ }^{\circ} \mathrm{C}$ temperature increase. The RCI (\%) caused by the high temperature occurs as a result of changes in the function (Barnabas et al., 2008) and the composition and structure of the cell membrane (Rahman et al., 2004). Exposure to the high temperature $\left(60^{\circ} \mathrm{C}\right)$ during heat treatment in the CMT test produced greater ability to discriminate between genotypes and safely identify the heat-tolerant genotypes. Our results demonstrate the ability of the genotypes to adjust their CMT under heat-stressed conditions. Furthermore, the research indicates sugarcane's physiological adaptation to heat stress or heat hardening as suggested by Blum and Ebercon (1981) for wheat. The differential response of sugarcane genotypes further suggests that this adaptation or hardening was under genetic control and should be amenable to genetic improvement. Although the impact of temperature heat stress is significant, it is also important to investigate the significance of phenological stage as suggested by Rahman et al. (2004) in cotton and Castro (2013) in corn and bean. 


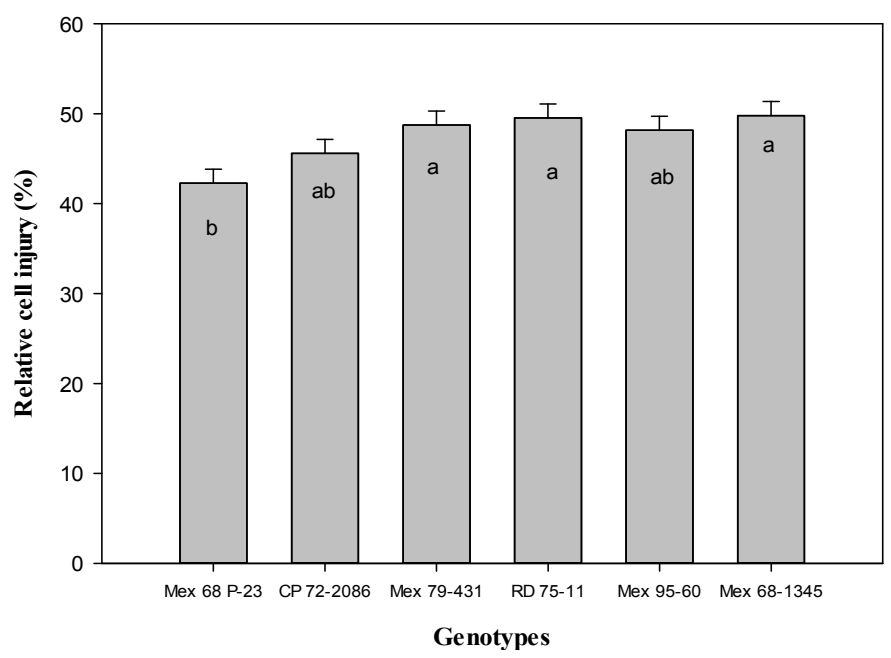

Figure 1. Mean performance of six sugarcane genotypes for RCI\% at the four phenological stages in field grown sugarcane under three temperature treatments. Standard errors are indicated by vertical bars

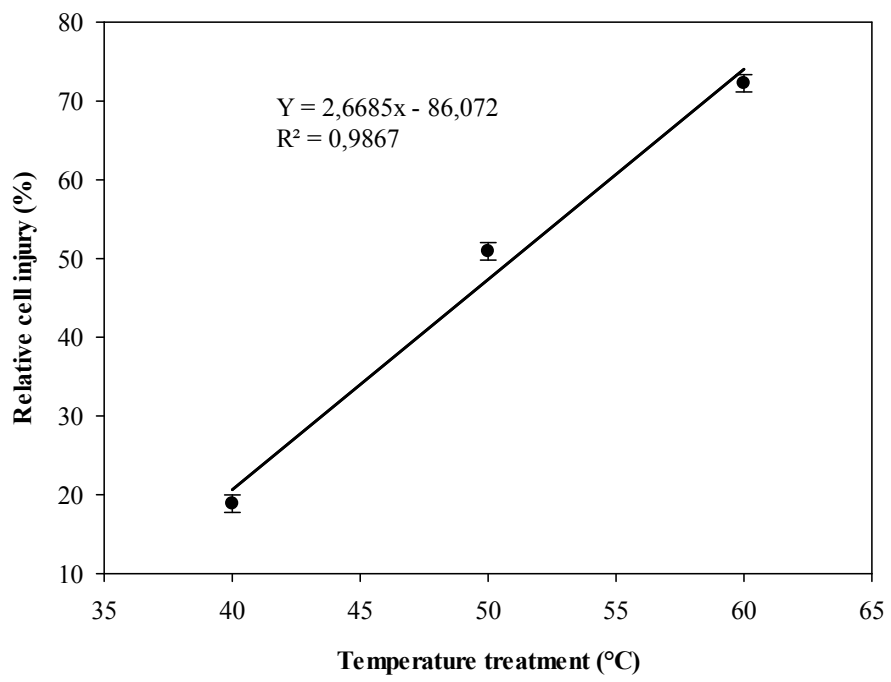

Figure 2. Relationship between temperature treatment and RCI\% under field of six sugarcane genotypes. Standard errors are indicated by vertical bars

\subsection{Effect of Phenological Stage}

Contrary to what might be expected, in our study, the stage of leaf development was not the most susceptible to heat (Figure 3). Among phenological stages, the means of RCI\% ranged between 43 and 54\%. These RCI\% values indicate a wide response in heat tolerance among phenological stages. At maturity, we found the highest $\mathrm{RCI} \%$ values, and at the tillering stage the lowest $\mathrm{RCI} \%$. Vegetative stage plant cells were less sensitive than mature plant cells, which coincides with Castro (2013) in corn and beans, but differing from those obtained by Fokar et al. (1998) in wheat. This means that at more advanced phenological stages, there are more possibilities that with the application of CMT, higher values of RCI\% are obtained and with this the possibility of identify genotypes with heat tolerance genes. However, results obtained by Saadalla et al. (1990a) indicate that CMT values obtained in sugarcane seedlings and flowering are highly associated and quite consistent. Similar results were obtained by Ismail and Hall (1999) in cowpea when using the CMT at the reproductive stage, and those obtained by Rahman et al. (2004) at the fruiting stage in cotton. In other words, the plant physiological processes differ in their response to heat stress from one phenological stage to another. Our data and results indicate that the determination of the $\mathrm{CMT}(\mathrm{RCI} \%)$ in a genetic improvement program for heat tolerance will depend on the crop, the objectives, the time available, and the number of genotypes to be evaluated. 


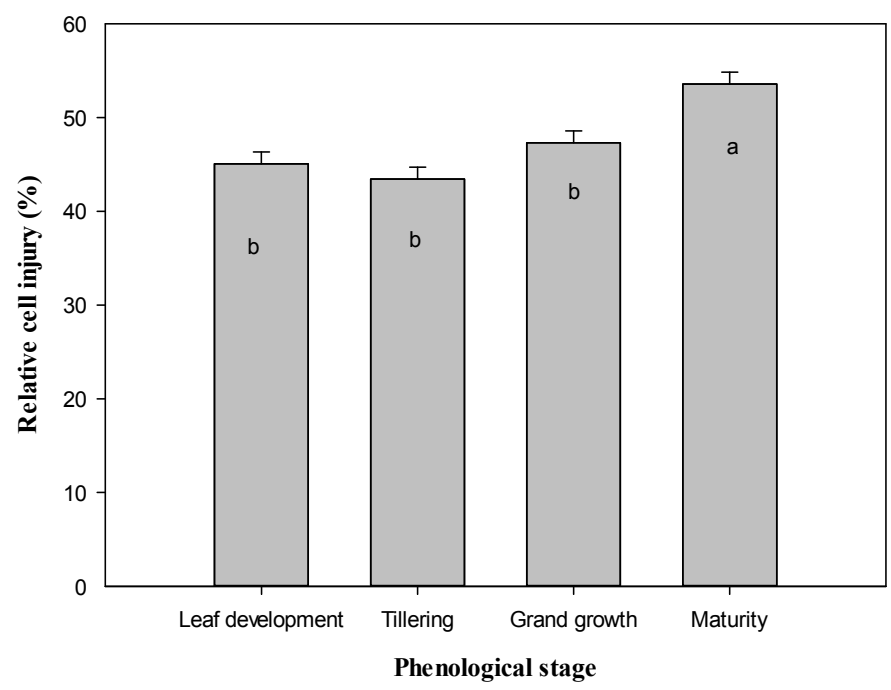

Figure 3. Mean performance of four phenological stages for RCI\% of six sugarcane genotypes in field grown sugarcane exposed to three temperature treatments. Standard errors are indicated by vertical bars

\subsection{Interactions}

The genotypes studied had a significant interaction (Figure 4) with the phenological stage $(\mathrm{P} \leq 0.01)$. The RCI (\%) in Mex 68-1345 and Mex 95-60 was higher in the grand growth stage, while in the rest of the genotypes this same condition was observed at the maturity stage. CP 72-2086, RD 75-11 and Mex 79-431 had a drastic increase in $\mathrm{RCI} \%$ from the grand growth stage to maturation, and the highest $\mathrm{RCI} \%$ values in the same stage. This suggests that these genotype cells would be more sensitive to temperature changes at the maturity stage. Gomathi et al. (2014) reported similar observations in sugarcane with the gradual increase in temperatures from $38,40,42$ and $44^{\circ} \mathrm{C}$, but with different time duration using the CMT technique. At the temperature levels studied, the plants were able to modify their cellular and metabolic response, which allows them to survive. The phenological stages studied also had a significant interaction $(\mathrm{P} \leq 0.01)$ with the exposure temperature (Figure 5). In all phenological stages, the RCI\% was significantly lower at $40{ }^{\circ} \mathrm{C}$. The greatest difference was in the leaf development stage (66\%) compared to the $60{ }^{\circ} \mathrm{C}$ treatment. The tillering stage $\mathrm{RCI} \%$ was consistently very similar to the grand growth and maturity stages at the 50 and $60{ }^{\circ} \mathrm{C}$ treatments. However, the greatest values were always at the $60{ }^{\circ} \mathrm{C}$ treatment. This indicates that there was a greater cell sensitivity in this phenological stage compared with the vegetative stage, where the response was a function of the exposure temperature.

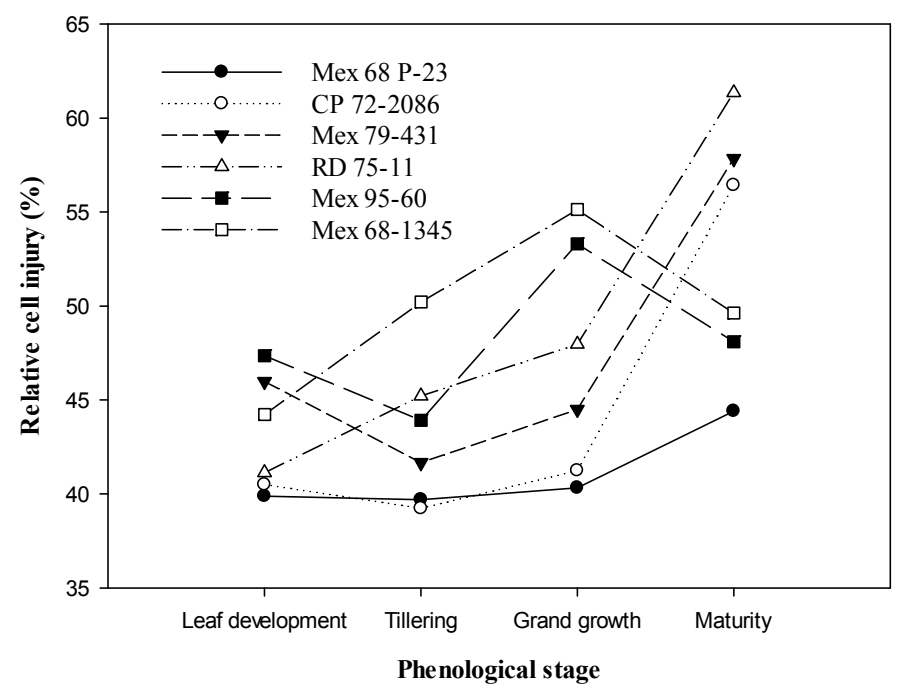

Figure 4. Relative cell injury (\%) as determined by the cell membrane thermostability (CMT) test on plants of six sugarcane genotypes at four phenological stages exposed to four treatment temperatures 


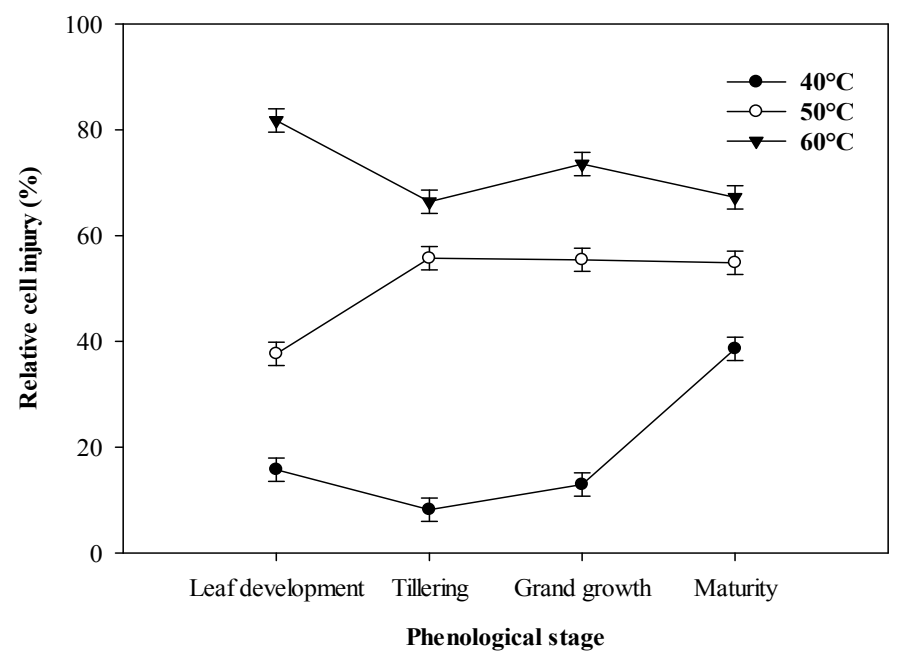

Figure 5. Relative cell injury (\%) from leaf disks of three temperature treatments at four phenological stages. Standard errors are indicated by vertical bars

It was important that although sugarcane genotypes responded differentially for RCI\%, their performance in temperature treatment and phenological stages were quite consistent. Our results suggest that heat tolerance based on CMT (RCI\%) can be improved using the existing genetic variability available within the commercial or experimental sugarcane germplasm. The goodness of the test was demonstrated by Castro et al. (2011) and Castro et al. (2014) in maize; Gomathi et al. (2014), Sudhakar et al. (2010), Gomathi et al. (2013), in sugarcane; Rahman et al. (2004), Ibrahim and Quick (2001) and Blum et al. (2001), Shanahan et al. (1990) in wheat; and Ismail and Hall (1999) in cowpea.

\section{Conclusion}

We conclude that the CMT test can be a useful screening procedure for selecting sugarcane genotypes that tolerate high temperature stress. It could be used in conjunction with a temperature trait of $60{ }^{\circ} \mathrm{C}$ during the maturity stage. This procedure predicts the ability of sugarcane genotypes to maintain yield and juice quality under stressful field conditions.

\section{References}

Barnabás, B., Jäger, K., \& Fehér, A. (2008). The effect of drought and heat stress on reproductive processes in cereals. Plant Cell Environment, 31, 11-38. https://doi.org/10.1111/j.1365-3040.2007.01727.x

Blum, A., \& Ebercon, A. (1981). Cell membrane stability as a measure of drought and heat tolerance in wheat. Crop Science, 21, 43-47. https://doi.org/10.2135/cropsci1981.0011183X002100010013x

Blum, A., Klueva, N., \& Nguyen, H. T. (2001). Wheat cellular thermotolerance is related to yield under heat stress. Euphytica, 117, 117-123. https://doi.org/10.1023/A:1004083305905

Bonnett, G. D. (2014). Developmental stages (Phenology). In P. H. Moore \& F. C. Botha (Eds.), Sugarcane: Physiology, Biochemistry, and Functional Biology (pp. 35-53). Ames, Iowa: John Wiley \& Sons, Inc.

Castro, N. S. (2013). Optimum temperature and phenological stage for determining cellular membrane thermostability in corn and bean. Phyton, 82, 249-254.

Castro, N. S., \& Huerta A. J. (2015). Response of sugarcane varieties (Saccharum officinarum L.) to NPK fertilization on dry land in southern Tamaulipas, Mexico. Revista Mexicana de Ciencias Agricolas, Publicación Especial, 11, 2225-2232. https://doi.org/10.29312/remexca.v0i11.804

Castro, N. S., Ramos, O. V. H., \& Huerta, A. J. (2012). Use of cell membrane stability to estimate heat tolerance in maize. Interciencia, 37, 921-926.

Castro-Nava, S., Ramos-Ortiz, V. H., Reyes-Méndez, C. A., \& Huerta, A. J. (2014). Grain yield, photosynthesis and water relations in two contrasting maize landraces as affected by high temperature alone or in combination with drought. Maydica, 59, 104-111.

Chen, J., Xu, W., Burke, J. J., \& Xin, Z. (2010). Role of phosphatidic acid in high temperature tolerance in maize. Crop Science, 50, 2506-2515. https://doi.org/10.2135/cropsci2009.12.0716 
Chen, T. H. H., Shen, Z. Y., \& Lee, P. H. (1982). Adaptability of crop plants to high temperature stress. Crop Science, 22, 719-725. https://doi.org/10.2135/cropsci1982.0011183X002200040006x

Fisher, R. A. (1985). Number of kernels in wheat crops and the influence of solar radiation and temperature. Journal of Agricultural Science, 105, 447-461. https://doi.org/10.1017/S0021859600056495

Fokar, M., Nguyen, H. T., \& Blum, A. (1998). Heat tolerance in spring wheat. I. Estimating cellular thermotolerance and its heritability. Euphytica, 104, 1-8. https://doi.org/10.1023/A:1018346901363

Gomathi, R., Shimala, S., Vasantha, S., \& Suganya, A. (2014). Optimization of temperature conditions for screening thermotolerance in sugarcane through temperature induction response (TIR) technique. International Journal of Science, 3, 5-18. https://ssrn.com/abstract=2573695

Gomathi, R., Yukashini, K., Shiyamala, S., Vasantha, S., Suganya, A., \& Rakkiyappan, P. (2013). Induced response of sugarcane variety Co 86032 for thermotolerance. Sugar Tech, 15, 17-26. https://doi.org/ $10.1007 / \mathrm{s} 12355-012-0192-7$

Ibrahim, A. M. H., \& Quick, J. S. (2001). Genetic control of high temperature tolerance in wheat as measured by membrane thermal stability. Crop Science, 41, 1405-1407. https://doi.org/10.2135/cropsci2001.4151405x

IPCC (Intergovernmental Panel on Climate Change). (2013). Summary for Policymakers. In T. F. Stocker, D. Qin, G. K. Plattner, M. Tignor, S. K. Allen, J. Boschung, ... P. M. Midgley (Eds.), Climate change 2013: The physical science basis. Contribution of Working Group I to the Fifth Assessment Report of the Intergovernmental Panel on Climate Change. Cambridge University Press, Cambridge. https://doi.org/ 10.1017/CBO9781107415324.004

Ismail, A. M., \& Hall, A. E. (1999). Reproductive-stage heat tolerance, leaf membrane thermostability and plant morphology in cowpea. Crop Science, 39, 1762-1768. https://doi.org/10.2135/cropsci1999.3961762x

Martineau, J. R., Specht, J. E., Williams, J. H., \& Sullivan, C. Y. (1979). Temperature tolerance in soybeans. I. Evaluation of a technique for assessing cellular membrane thermostability. Crop Science, 19, 75-78. https://doi.org/10.2135/cropsci1979.0011183X001900010017x

Masuka, B., Araus, J. L., Das, B., Sonder, K., \& Cairns, J. E. (2012). Phenotyping for abiotic stress tolerance in maize. Journal Integrative Plant Biology, 54, 238-249. https://doi.org/10.1111/j.1744-7909.2012.01118.x

Rahman, H., Malik, S. A., \& Saleem, M. (2004). Heat tolerance of upland cotton during the fruiting stage evaluated using cellular membrane thermostability. Field Crops Research, 85, 149-158. https://doi.org/ 10.1016/S0378-4290(03)00159-X

Reynolds, M. P., Balota, M., Delgado, M. I. B., Armani, I., \& Fischer, R. A. (1994). Physiological and morphological traits associated with spring wheat yield under hot irrigated conditions. Australian Journal of Plant Physiology, 21, 717-730. https://doi.org/10.1071/PP9940717

Saadalla, M. M., Quick, J. S., \& Shanahan, J. F. (1990b). Heat tolerance in winter wheat: II. Membrane thermostability and field performance. Crop Science, 30, 1248-1251. https://doi.org/10.2135/cropsci1990. 0011183X003000060018x

Saadalla, M. M., Shanahan, J. F., \& Quick, J. S. (1990a). Heat tolerance in winter wheat: I. Hardening and genetic effects on membrane thermostability. Crop Science, 30, 1243-1247. https://doi.org/10.2135/cropsci 1990.0011183X003000060017x

SAS Institute. (2010). SAS/STAT User's guide (Version 9.2, p. 1689). SAS Institute, Inc. Cary, North Carolina, USA.

Shanahan, J. F., Edwards, I. B., Quick, J. S., \& Fenwick, J. R. (1990). Membrane thermostability and heat tolerance of spring wheat. Crop Science, 30, 247-251. https://doi.org/10.2135/cropsci1990.0011183X0030 $00020001 x$

Sudhakar, P., Latha, P., \& Badu, A. M. (2010). Evaluation of sugarcane genotypes for high water use efficiency and thermostability tolerance under imposed moisture stress at formative stage. Sugar Tech, 12, 72-75. https://doi.org/10.1007/s12355-010-0015-7

Sullivan, C. Y. (1972). Mechanisms of heat and drought resistance in grain sorghum and methods of measurement. In N. G. P. Rao \& L. R. House (Eds.), Sorghum in the seventies. Oxford \& IBH Publishing Co. New Delhi, India. 
Sullivan, C. Y., \& Ross, W. M. (1979). Selecting for drought and heat resistance in grain sorghum. In H. Mussell \& R. Staple (Eds.), Stress physiology in crop plants. Wiley Interscience. John Wiley and Sons. New York.

Thiaw, S., \& Hall, A. E. (2004). Comparison of selection for either leaf electrolyte-leakage or pod set in enhancing heat tolerance and grain yield of cowpea. Field Crops Research, 86, 239-253. https://doi.org/ 10.1016/j.fcr.2003.08.011

Tripathy, J. N., Zhang, J., Robin, S., Nguyen, T. T., \& Nguyen, H. T. (2000). QTLs for cell membrane stability mapped in rice (Oryza sativa L.) under drought stress. Theoretical and Applied Genetics, 100, 1197-1202. https://doi.org/10.1007/s001220051424

Trivedi, A. K. (2015). Adaptations and mechanisms of heat stress tolerance of plants. Academic Research Journal of Agricultural Science and Research, 3, 151-160.

Wahid, A. (2007). Physiological implications of metabolite biosynthesis for net assimilation and heat-stress tolerance of sugarcane (Saccharum officinarum) sprouts. Journal of Plant Research, 120, 219-228. https://doi.org/10.1007/s10265-006-0040-5

Wahid, A., \& Close, T. J. (2007). Expression of dehydrins under heat stress and their relationship with water relations of sugarcane leaves. Biologia Plantarum, 51, 104-109. https://doi.org/10.1007/s10535-007-0021-0

Wahid, A., Gelani, S., Ashraf, M., \& Foolad, M. R. (2007). Heat tolerance in plants: An overview. Environmental and Experimental Botany, 61, 199-223. https://doi.org/10.1016/j.envexpbot.2007.05.011

Yildirim, M., Bahar, B., Koç, M., \& Barutçular, C. (2009). Membrane thermal stability at different developmental stages of spring wheat genotypes and their diallel cross populations. Tarim Bilimleri Dergisi, 15, 293-300. https://doi.org/10.1501/tarimbil_0000001103

\section{Copyrights}

Copyright for this article is retained by the author(s), with first publication rights granted to the journal.

This is an open-access article distributed under the terms and conditions of the Creative Commons Attribution license (http://creativecommons.org/licenses/by/4.0/). 